\title{
The writing on the wall? John Ingram's verse and the dissemination of Catholic prison writing
}

\author{
Alison Shell ${ }^{1}$ \\ University College London, Gower Street, London WC1 6BT \\ Email:a.shell@ucl.ac.uk
}

\section{This article has been accepted for publication and will be published in revised form in British Catholic History, 33:1 (May 2016)}

The strong association between prison writing and writing on walls, whether by graffiti or carving, is as true of Tudor and Stuart England as of other times and places. Yet even if prisonwriters associated themselves with the idea of writing on a wall, they need not have done so in reality. This article considers the topos in the writings and afterlife of the Catholic priest, poet and martyr John Ingram, and asks whether it is to be taken at face value.

Ingram's verse, composed in Latin and mostly epigrammatic, survives in two contemporary manuscripts. The notion that the author carved his verses with a blunt knife on the walls of the Tower of London while awaiting death derives from a previous editorial interpretation of a prefatory sentence within the more authoritative manuscript of the two, traditionally held to be autograph. However, though several Tudor and Stuart inscriptions survive to this day on the walls of the Tower of London, no portions of Ingram's verse are among them, nor any inscriptions of similar length and complexity. Ingram might instead have written his verse down in the usual way, using wall-carving as a metaphor for the difficulty of writing verse when undergoing incarceration and torture.

Key words: Prison-writing, Graffiti, Epigram, Catholic writing, Martyrs

Illustrations:

[Figure no. 1: MS Anglia A.VII.8]

For lack of ink, the candle coal,

For pen a pin I use,

The which also I may allege

In part of my excuse:

For said it is of many men,

And such as are no fools,

A workman is but little worth

\footnotetext{
${ }^{1}$ My thanks to the following individuals and organisations for help with this paper: Bridget Clifford (of the Royal Armouries), Anne Dillon, Arnold Hunt, Gerard Kilroy, Molly Murray, George Roberts and Sarah Smith (of Historic Royal Palaces), the Archivum Britannicum Societatis Jesu and its archivist Rebecca Somerset. Versions of it were given in Krakow in September 2014, and at Northumbria University in November 2014; in each case I would like to thank the organisers of the conference for inviting me, and the audience members for their helpful comments.
} 
If he do want his tools ... ${ }^{2}$

These words, taken from a verse-letter composed by the recusant prisoner Francis Tregian, epitomise the metaphorical link between improvised resources and prisoners' heroic battles against privation. We do not know whether Tregian actually did make a pen out of a pin and collect soot from candles to use for his ink. ${ }^{3}$ But he certainly exploits the idea that this is correct behaviour for a prison writer - and since he represents himself as having paper, he appears better resourced than some who could only write on the walls that held them captive. The strong association between prison-writing and writing on walls, whether by graffiti or carving, is as true of Tudor and Stuart England as of other times and places. Yet just because prison-writers were associated with the idea of writing on a wall, they need not necessarily have done so. This article considers the topos in the writings and afterlife of Tregian's contemporary, the Catholic priest, poet and martyr, John Ingram, and asks whether it is to be taken at face value.

Ingram was born in 1565, possibly in Herefordshire - a remote area of England where Catholicism remained strong throughout the 1560s and beyond - and educated first in Worcestershire, then at the English College in Rheims, the Jesuit College at Pont-àMousson, and the English College in Rome. He was ordained in 1589 and went to Scotland around 1592, where he consorted with Catholic nobles. Following an outcry against Catholics in Scotland, he was obliged to flee across the border. He was captured in the North of England in November 1593 and imprisoned successively at Berwick, Durham, York and the Tower of London, where he appears to have written his verses. Subsequently he was sent north again to York, Newcastle and Durham, where he stood trial. Even though there was no evidence that he had exercised any priestly function in England, he was convicted under the statute that made the mere presence of a Catholic priest in England high treason. He was hung, drawn and quartered in Gateshead on 26 July 1594, and his quarters were sent across the river to Newcastle. In 1929 he was beatified, and to this day a commemorative walk in his honour from Newcastle to Gateshead takes place every year around his execution date. ${ }^{4}$ His verse, composed in Latin and mostly epigrammatic, survives in two contemporary manuscripts. One, traditionally held to be autograph, forms part of the 17th-century Catholic antiquary

\footnotetext{
${ }^{2}$ P. A. Boyan and G. R. Lamb, Francis Tregian: Cornish Recusant (London: Sheed \& Ward, 1955), 146147. See also Raymond Francis Trudgian, Francis Tregian, 1548-1608, Elizabethan Recusant: A Truly Catholic Cornishman (Brighton: Alpha Press, 1998). On writing with a pin in prison, see the story of Lady Jane Grey in John Foxe, Acts and Monuments (London, 1563), 1714.

${ }^{3}$ On improvised paper, see T.S. Freeman, 'Publish and Perish: The Scribal Culture of the Marian Martyrs', in Julia C. Crick and Alexandra Walsham, eds., The Uses of Script and Print, 1300-1700 (Cambridge: Cambridge University Press, 2004), 235-54, at pp. 237-238.

4 This summarises the biographical detail in M. J. Cashman, 'The Gateshead Martyr', Recusant History, 11 (1971):121-132, an expanded and altered version of this article, 'Bl. John Ingram, 1565-1594: The Gateshead Martyr', Northern Catholic History, 29 (1989): 2-19, and John Wainewright's entry for Ingram in the online Catholic Encyclopaedia (www.newadvent.org). On the annual walk, see the website of the Catholic Diocese of Hexham and Newcastle (www.rcdhn.org.uk/about_the_diocese/saints/johningram.php). The name of John Ingram is jotted down as part of a pen-trial on p.18 of a well-known recusant manuscript, Bodleian MS Eng. poet. b. 5, but given its mid-seventeenth-century date, this must refer to a later individual. See Frank M. McKay, 'A Seventeenth-Century Collection of Religious Poetry: Bodleian Manuscript Eng. poet. b. 5', Bodleian Library Record, 8 (1970): 185-91.
} 
Christopher Grene's collections, and a contemporary copy was also circulated by the priest Richard Holtby. ${ }^{5}$

Tudor and Stuart prison writing has attracted much attention recently. ${ }^{6}$ Its scholars emphasise the notion that the early modern prison should not be seen as an existential experience where the isolated prisoner communed primarily with himself and God, but as a place where like-minded people had considerable opportunity for interchange. Moreover, despite the imperative of confinement, the boundaries between inside and outside were permeable and often permeated. Robyn Adams, for instance, has commented that 'the prison wall ... is ... a site of enclosure and a visible barrier, but one that can be penetrated and through which subversive material can be exchanged. ${ }^{17}$ Taking her bearings from network analysis, Ruth Ahnert confirms that 'prison communities were not bound by prison walls'. ${ }^{8}$ Writing was an especially important way for prisoners to form bonds with each other and maintain contact with the outside world, and Molly Murray has described the early modern prison as 'a site of culture, one that ought to be considered alongside the court and the university as a place of significant textual, and literary, production'. ${ }^{9}$

The recent surge of interest in prison writing has complicated our view of how that writing took place. While orders controlling writing and reading may suggest that these were relatively common under normal circumstances, there was also enormous variation in whether prisoners were allowed the wherewithal to write; in some cases it was hardly regulated at all, in other cases it could be cracked down upon severely. ${ }^{10}$ Catholic prisoners were, of course, not the only ones to be deprived of writing materials, but they had a more systematised response than many to this hardship. Having pen, ink and paper confiscated, or - worse - being tortured to the extent that it was difficult or impossible to write, were privations that would have enabled co-religionists to build up a case for one's

\footnotetext{
5 Stonyhurst College, A.VII.8. This manuscript is incomplete, and John Hungerford Pollen's edition of Ingram's verse, part of epigram XVIII, poems XIX and XX and the authorial end-note are taken from a contemporary copy by the priest Richard Holtby (Stonyhurst College, A.II.12, pp. 33-34): see Documents Relating to the English Martyrs, ed. John Hungerford Pollen, S.J. (London: Catholic Record Society, 1908), 270-285. A third, later copy survives in Grene, Collectanea, N. i. pp. 41-45r (not pp. 41-46 as given by Pollen). All three manuscripts are currently held at the British Jesuit Archives, Mount Street, London. An English verse signed 'I.I.', which survives in an early edition of Robert Southwell's verse, may also be his: see Appendix.

${ }^{6}$ Robyn Adams, '"The service I am here for": William Herle in the Marshalsea Prison, 1571', Huntington Library Quarterly (hereafter HLQ), 72 (2009): 217-238, esp. pp. 227-37; Ruth Ahnert, The Rise of Prison Literature in the 16th Century (Cambridge: Cambridge University Press, 2013); T. S. Freeman, 'The Rise of Prison Literature', HLQ, 72 (2009): 133-146; Peter Lake and Michael Questier, The Antichrist's Lewd Hat: Protestants, Papists and Players in Post-Reformation England (New Haven: Yale University Press, 2002), chap. 6; Molly Murray, 'Measured Sentences: Forming Literature in the Early Modern Prison', $H L Q$, 72 (2009): 147-67; Paul Strauss, In Hope of Heaven: English Recusant Prison Writings of the 16th Century (New York: Peter Lang, 1995); Rivkah Zim, 'Writing Behind Bars: Literary Contexts and the Authority of Carceral Experience', HLQ, 72 (2009): 291-311. See also Edward Douglas Pendry, Elizabethan Prisons and Prison Scenes, 2 vols (Salzburg: Institut für englische Sprache und Literatur, Universität Salzburg, 1974).

7 'William Herle', 237.

8 Ahnert, Rise, 76.

9 'Measured Sentences', p. 150.

${ }^{10}$ In certain contexts, writing was not only permitted but facilitated by officials (Murray, p. 158). Freeman comments that payments by prisoners for jailers' services. were built into the system ('Rise of Prison Literature': 141; but see pp. 144-45 on searches for pen, ink and paper). On the confiscation of writing materials, see also Ahnert, Rise, 21, 31 .
} 
exemplary suffering and confessorship, via such means as letters and biographical narratives. One example is the anecdote circulated by Henry Garnet about Robert Southwell's time in prison; Southwell, he claimed, scratched words with a pin in his breviary because he had no access to writing materials. Garnet writes, 'I have turned over each leaf of the breviary curiously, and have not found one single sign made with ink, from which it follows, that he was never granted the commodity of writing to his friends outside. ${ }^{11}$ Garnet's logic is shaky, but the idea would certainly have helped to shape the Southwell cult.

All this is important when considering Ingram's writing: both how he himself presented it, and how it was preserved by the custodians of his memory. The manuscript of his verse traditionally held to be autograph has a brief prefatory remark, which appears to be in the same hand, telling the reader that he carved his epigrams 'with a blunt knife on the walls of the Tower of London while he daily awaited death'. ${ }^{12}$ [Image to be inserted here. Caption: MS Anglia A.VII.8, heading to the manuscript of Ingram's verse traditionally held to be autograph. Reproduced by kind permission of the Archivum Britannicum Societatis Jesu] As observed above, there is certainly a strong correspondence, at this or any date, between carving and writing on walls and prison writing: no doubt because, in many cases, a wall is the only writing-surface available to a prisoner, and because they are obvious hobbies for anyone with too much spare time. ${ }^{13}$ The Catholic priest Henry Morse wrote of one prison he visited: 'The ... chamber walls, made entirely of stone, were bedaubed with texts of Scripture, scribbled in charcoal, and with scraps of verses composed according to the disposition and circumstances of the several tenants thereof. ${ }^{14}$ Given this context, it is not surprising that the idea of writing on walls, turning a means of enclosure into a means of expression, came to emblematise resistance.

But what were the practicalities of writing on a wall? As Morse's description suggests, one could write with chalk or with charcoal. More permanently, a prisoner could carve the stone walls with the knife he was given for meals, which is what the introduction to the autograph manuscript could be referring to, and which has been taken at face value by the handful of people who have studied Ingram. ${ }^{15}$ The relative permanency of a carved

11 Garnet to Claudio Acquaviva, Father General of the Jesuits, 7 March 1595: quoted in Pierre Janelle, Robert Southwell the Writer: A Study in Religious Inspiration (London: Sheed \& Ward, 1935), 69-70.

12 'E $\pi ү \rho \alpha ́ \mu \mu \alpha \tau \alpha$ parietibus turris Londinie[n]sis rudi cultro insculpta cum indies mortem expectaret (see illustration). Except where indicated, I have used Pollen's edition and English translations; it should be noted that, on some occasions, he silently emends the capitalisation and punctuation of the originals. The tradition of assuming that the epigrams are autograph derives from a contemporary annotation on the manuscript, ' $\mathrm{M}^{\mathrm{r}}$ John Engrams owne hand writinge', and a later note (probably Grene's) on a cover-sheet to the manuscript, 'Domini Joannis Ingrami. M. Carmina propria manu exarata in carcere'. I know of no reason to query it; the hand is similar to letters of Ingram's written earlier in his life (reproduced in Pollen's edition), and though the writing is more uneven than in these, the difference could have been a result of privation and torture (see below).

${ }^{13}$ See Ahnert, Rise, 33-42, 53; and Juliet Fleming, Graffiti and the Writing Arts of Early Modern England (London: Reaktion, 2001), 55-56.

14 See Philip Caraman, Henry Morse: Priest of the Plague (London: Longmans, Green, 1957), 127.

15 See Brian A. Harrison, The Tower of London Prisoner Book (Leeds: Royal Armouries, 2004). Harrison lists several inscriptions carved on the stone walls by prisoners contemporary to Ingram, suggesting that the walls were unplastered. Surviving inscriptions in the Tower of London appear to demonstrate that both space and suitable surfaces were limited; they are mainly carved on the finely dressed masonry surrounds to windows and doors, not on the rougher stone used for the body of the walls. My thanks to George Roberts for his help with this. 
inscription would certainly have made it appealing to Catholic prisoners as a means of witnessing to one's faith, and leaving inspiring messages for successors. ${ }^{16}$ However, there are also reasons to be sceptical. Ingram wrote a lot of verse - 20 poems totalling 188 lines in all - and it would have taken an immense amount of time even to scratch this on a wall. The recent catalogue of Tower of London inscriptions not only records none of Ingram's verses, but gives little of remotely comparable length or sophistication. ${ }^{17}$ Much more typical, both in content and length, are the three inscriptions by Ingram's coinmate and fellow priest, Henry Walpole: two giving his name and titles, the third listing himself alongside the four Western Doctors of the church, Saints Jerome, Ambrose, Augustine and Gregory. ${ }^{18}$ Ingram is never recorded as out of his captors' hands from the time he was brought into the Tower of London until the time when he was brought up to Gateshead and executed; as commented above, the provenance and penmanship of the earliest manuscript suggests that it is in Ingram's hand; and this in turn would show that, at some point during his period of imprisonment, he did have access to pen and paper. It seems, therefore, much more likely that they were written in the usual way, rather than carved on the wall of Ingram's cell.

So is Ingram's claim that he scratched his verse with a blunt knife no more than a metaphor for incarcerated creativity that his audience would not necessarily have taken at face value? That is certainly one possibility, but another and more complex one is suggested by Epigram X, 'Of the Knife He Had in the Tower':

Why has Fanner, the keeper of the keys, given me a knife blackened with all manner of rust, and without a point?

An Irishman, who had followed the dread career of bloody Mars,

Wished to lay violent hands upon himself. ${ }^{19}$

Thou also hadst once been girt with Pallas' gleaming sword;

And in thy life hast followed her banner.

Yet thou wouldst never be willing to destroy thy wretched life with the steel,

On that account was the sharp knife refused thee.

Men of kindred professions he has treated us in the same way,

Lest thy fate should harm thy keeper.

Lo, I confess that I have ever been a friend of the nine muses,

But Minerva the wise differs far from Mars the ferocious.

In presence of all I desire to seal my faith with my blood,

That my death may be to them a cause of a holy life. ${ }^{20}$

16 Harrison, Prisoner Book, notes the following Catholic prisoners from around Ingram's time: George Beisley, 489; James Bosgrave, 497; John Colleton, 480, 494; Philip Howard, 17th Earl of Arundel, 477, 480); Nicholas Roscarrock, 497; Tipping (first name not known), 477; Henry Walpole, 493. In some cases these prisoners are only known to be Catholic because of their inscriptions.

17 The fact that they are not listed in Harrison, Prisoner Book, does not obviate the possibility that they may have disappeared in rebuilding, or that Ingram wrote them on the wall in pencil or charcoal. I have also viewed the inscriptions listed as fragmentary by Harrison, and found no evidence that they preserve Ingram's work.

18 See above.

19 The Irish soldier mentioned in the epigram is probably either Patrick Cullen/Collen or John Annias, who entered England on an errand to murder the queen and were committed in February 1594. Cullen was released and rewarded for his services to the tune of $£ 10$ on 17 May 1594; Annias was still a prisoner on 24 June 1599 (Harrison, 261).

20 De cultro quem in Turri habuit / Cur mihi cultellum varia rubigine nigrum / Absque dedit Fanner cuspide clave potens? / Horrida sanguinei sectatus proelia Martis (Holtby: mortis) / Hibernus voluit se 
To summarise the argument of this dense epigram: Ingram is comparing an Irish soldier, his co-prisoner and the follower of Mars, god of war, to himself as scholar and friend of Pallas Athena, goddess of learning. The difference between them is that the soldier is suicidally inclined, while Ingram is in jail precisely because he is not willing to risk spiritual destruction by renouncing the Catholic faith. By the same token, he would never commit the sinful act of suicide; yet despite the fact that he poses no threat, he has been given a blunt knife by the jailer so that he cannot stab himself. Since blunt knives were sometimes given to prisoners during periods of torture in case they killed themselves, and since there is external evidence that Ingram underwent torture at various points, we may be intended to read the knife itself as an oblique reference to being tortured. ${ }^{21}$ But even without this potential additional meaning, Ingram's was a situation in which anyone might be inclined to compare the act of writing to carving with a blunt knife.

In fact, the knife undergoes an ontological reversal, becoming an instrument not of damage, but of perpetuation. Following the hint in the poem's title, we are meant to think of it as an extempore chisel for lapidary verses, metaphorically if not literally: inscribing Ingram's own defiance and signifying the impotence of the persecutor. The disparate professions of soldier and scholar become paradoxically united through the idea of knives, which are compared to the sword of the former and the pen, or intellectual acuity, of the latter. This also makes the bluntness of Ingram's knife a reference to the fact that he is deprived of scholarly resources. Complaints at privation and the expression of a desire to publish against the odds are - understandably enough - constant themes in prison verse, as shown in the poem of Francis Tregian's with which this article began. This variant of the modesty topos so familiar in early modern writing can also act as a way of pre-empting criticism: the writer who cannot lay his hands on pen, ink and paper is likely to be away from his books, at best, and suffering extreme mental and physical hardship at worst. Ingram's verses do end with his apology for any faults that the lack of reference material might have occasioned: 'Seeing that the time was one ill-suited for writing poetry, and that there was a total dearth of books needful for such a task, it will not be strange that some faults should have crept in which a generous reader will either courteously condone, or, what is better, correct.' ${ }^{22}$

There is something a little disingenous in this; only a Momus would react harshly to poetry written in the circumstances Ingram was experiencing. But Ingram was, it is true, composing in an ambitious genre. The epigram was a learned poet's pastime, drawing on

violare manu. / Tu quoque cinctus eras rutilanti Palladis ense; / Eius et in vita castra secutus eras. / Neu (Holtby: Non) velles tristem ferro dirumpere (Holtby: disrumpere) vitam, / Non datus idcirco culter acutus erat. / Arte pares igitur forma tractavit eadem / Neu (Holtby: No[n]) tua custodi Parca nociva foret. / Ecce novem fateor Musis me semper amicum, / Discrepat ast sapiens Marte Minerva fero. / Omnibus opto fidem coram signare cruore / Fiat ut his vitae mors mea causa piae.

${ }^{21}$ For an account of Ingram's torture, see William Hutton's notes, Stonyhurst College, Anglia A, vol.6, pp. 41-48, transcribed by John Morris, The Troubles of our Catholic Forefathers, series 3 (London: Burns and Oates, 1877), at 314. For John Gerard's account of how Henry Walpole's handwriting changed after torture, see John Gerard: The Autobiography of an Elizabethan, trans. Philip Caraman, intro. Michael Hodgetts (Oxford: Family Publications, 2006), 105 (see also p. 114 for sharp objects being confiscated). For blunt knives being issued to prisoners undergoing torture, see John Morris, The Condition of Catholics Under James I (London: Longmans, Green, 1877), 189.

${ }^{22}$ Cum nec tempus rerum poeticarum aptum, nec liber ullus tali negotio necessarius sese obtulerit, non mirum erit si aliqua irrepserint, a candido lectore vitia [aut] aeque bonique concedenda, vel, quod mallem, emendanda. (Transcription corrected from Pollen's.) 
classical models like Martial, Catullus and the poets of the Greek Anthology, and Renaissance humanist poets such as Clément Marot, Theodore de Bèze, and England's own Ben Jonson. ${ }^{23}$ Ingram is likely to have been well aware of this heritage, since despite his protestations - his verse is highly sophisticated and allusive, operating on a different level from many English Catholic poets of his time. ${ }^{24}$ A recusant's life or a martyr's death may or may not accompany literary expertise, and Ingram's verse takes us into a different world from Tregian's good-humoured doggerel; indeed, it implies a very different type of audience, which one can glimpse in his 'Ode showing the gratitude of his soul to those places in which he had learned the gentle arts': ${ }^{25}$

I long to pay due thanks to those cities

Which once on a time taught me their arts.

Flanders, thou that flashest with war, and which for the fruit of the soil,

Ownest no two equals in all Europe,

Thou didst teach me the sweet words of the Roman tongue,

And did make me bind all well unto the wheel.

France, thou of old second to none in holiness,

And skilled often to nourish learned men within thy bosom,

Thou dost make me know Cicero the father of Latin oratory,

Thou dost make me know how to sound the measures of the gladsome lyre.

Rome, thou of old sprinkled with the blood of thy founder,

Rome, now the fount of faith, the pinnacle of holiness,

Under thy tuition I learnt wisdom and Christ in the sacred text,

And to raise anointed hands unto heaven.

Flanders, Realm of France, and Latium, hail:

Your honour grows in the heart of Ingram. ${ }^{26}$

Ingram addresses men like himself in this ode -- fervent Catholics, but also urbane and classically educated -- and the references to fighting invite one to glance back to his epigram on the blunt knife, where scholarship is compared to combat. Neo-Latin, the ordinary international means of communication, could be seen as a potent weapon for the Catholic cause; Ingram's poems are potentially pan-European in their language and

23 Andrew W. Taylor, 'Between Surrey and Marot: Nicolas Bourbon and the Artful Translation of the Epigram', Translation and Literature, 15 (2006): 1-20.

24 Ingram's habit of playful allusiveness is demonstrated in lines 5-6 of epigram XIV: 'We live in the Lord; when moved we are moved by Him. / God immovable moving all things by His nod' (Vivimus in Domino motique movemur ab (Holtby: in) ipso / Immobili nutu cuncta movente Deo). This piously parodies a famous passage from Horace: '... monarchs themselves are under the power of Jove, who in the glory of his triumph over the Giants moves the whole universe with the nod of His brow' (reges in ipsos imperium est Iovis, / clari Giganteo triumpho, / cuncta supercilio moventis): Odes, 3:1, 6-8. Translation taken from Niall Rudd, ed. Horace: Odes and Epodes (Cambridge, Mass., Harvard University Press, 2004), 140-141.

25 Tregian's verse was written to his wife: see Boyan and Lamb, Francis Tregian, 146.

26 Carmen grati animi demonstrativum ad loca illa in quibus bonas artes imbiberat / Urbibus exopto grates persolvere dignas / artes me quondam quae docuere suas. / Flandria quae bello gliscis, quaeque ubere glebae / Europa socias nescis habere duas, / Dulcia Romanam docuisti verba loquelam, / fecisti et recte nectere cuncta rotae. / Gallia, quae quondam nulli pietate secunda / saepe sinu doctos docta fovere viros, / Scire facis Marcum latio sermone parentem, / scire facis laetae metra sonare lyrae. / Roma tui quondam structoris sanguine sparsa, / Roma modo fidei fons pietatis apex. / Te sophiamque sacro textu Christumque magistra / atque unctas didici tollere ad astra manus. / Flandria, Francorum regnum, Latiumque valete, / vester in Ingrami pectore crescit honos. 
referential range, deriving from and contributing to the robust tradition of neo-Latin martyrological writing fostered within the English Catholic colleges overseas. ${ }^{27}$

At first glance the 'Ode' may seem less concerned than others with the circumstances of Ingram's imprisonment, but pondering its most difficult passage suggests another conclusion. Part of Ingram's address to the personified city of Flanders, 'Thou didst teach me the sweet words of the Roman tongue, / And didst make me bind all well unto the wheel,' provoked John Hungerford Pollen to write: 'I am unable to ascertain the meaning of this line'. ${ }^{28}$ However, it makes sense if read as referring to St Catherine of Alexandria, who was tortured on a spiked wheel; Ingram's glancing reference to torture here is very reminiscent of the reference to his blunt knife, discussed above. Ingram had a particular devotion to St Catherine, since he was ordained on 25 November, her feastday, and captured in England on the same day several years later. In another epigram, he writes, 'What chance was it, what cause, or what mistake that I should have been taken / On the day dedicated to thee, holy Catherine?', then, addressing himself, 'After the lapse of years it has fallen out that thou shouldst confess thyself a priest / On the day on which thou wast happily made one. ${ }^{29}$ This epigram comes directly before the 'Ode': a clue that the sequence of verses is important, and that the reader should glance back to the earlier poem to pick up on Ingram's identification of himself with St Catherine. ${ }^{30}$

Ingram's characterisation of himself as actively embracing torture and death follows on from the way he compares his own arraignment to Catherine's, translated by Pollen as follows: 'The maiden filled with the most high God forfeited / Her chaste life beneath the savage sword of a heartless tyrant. / Thou standing bound in the midst of so many armed foes / Wilt give thyself piece by piece a sacrifice to the Immense God.' ${ }^{31}$ Pollen is paraphrasing here, and if the line were translated more literally, a possible reading would be: 'You will give [yourself] to the immense God through small pious pieces.' The word frusta is the plural of frustillum, a rare word meaning 'a small piece' or 'little bit', and Ingram's use of the diminutive, frusta, suggests particularly small pieces. ${ }^{32}$ The epigram, the shortest of all classical poetic genres, is here being used to play with the idea of littleness. Being chopped into small pieces also recalls the Elizabethan Catholic priest's all-too-common fate of hanging, drawing and quartering, which Ingram correctly anticipated for himself in 'A Merry Epigram on his Tomb':

27 See Anne Dillon, The Construction of Martyrdom in the English Catholic Community, 1535-1603 (Aldershot: Ashgate, 2003), and Christopher Highley, Catholics Writing the Nation in Early Modern Britain and Ireland (Cambridge, Cambridge University Press, 2008).

${ }^{28}$ English Martyrs, 281.

${ }^{29}$ Ut caperer fuerit casus, quae causa vel error / Diva tibi sacro, quis, Catharina die? ... Esse sacerdotem cecidit volventibus annis / Tempore te fassum quo bene factus eras. (Epigram XVIII, lines 1-2, 13-14; the last two lines are taken from Holtby).

${ }^{30}$ Ingram's autobiographical allusiveness could be challenging even for his contemporaries: Holtby remarks that 'these and, and ( $\mathrm{sic}$ ) diuers other extremities he endured as may appeare by his Letters, and certaine Epigrames he made during his restraint the copies whereof I haue here, written unto you: wherein many thinges are something obscure to understand, whiche you may perhaps more easily knowe, by the circumstances and accidentes of his emprisonment and usage while he was in those partes, as you haue more fitt oportunitie to know them then I' (A.II.12, p. 32).

31 Epigram XVIII, lines 7-10: Summi plena dei crudelis virgo tyranni / Sub saevo castum perdidit ense caput, / Stans captus medios inter tot tela, tot hostes, / Te dabis immenso per pia frusta Deo.

${ }^{32}$ See the entry for the word in Charlton T. Lewis and Charles Short, A Latin Dictionary (Oxford: Oxford University Press, this ed. 1980). 
Rocks are quarried, the entrails of the earth,

That Dives may have living rock for his tomb.

No tomb seek I; and yet shall there be a living tomb

For my lifeless body — the carrion-crow. ${ }^{33}$

Showing its author at his most blackly humorous, this points to the fact that it was common for the bodies of Catholic priests to remain unburied; sometimes quartered, they were put in a public place or places as an admonition, high up to discourage the relichunters, for as long as they remained undecayed or uneaten as carrion. As Ingram's title suggests, he is making a bid for an alternative memorial in verse - if he is unable to have an inscription physically on his tomb, it can at least be about his tomb - and through onomastic punning, he associates his own name not only with that title, but with the very genre of verse he uses here and elsewhere. The word 'epigram' is Greek in derivation, and one of the main meanings of the word $\dot{\varepsilon} \pi \mathrm{l}$ is 'in'. Despite the fact that 'epigram' is a commonly naturalised word in classical Latin, the autograph manuscript of Ingram's verse displays it in Greek characters no fewer than four times, drawing attention to the pun on 'Ingram' and 'epigram'. ${ }^{34}$

Writing in stone has, at least potentially, a physical longevity that most other forms of writing do not, and tombs are closely associated with lapidary inscription. ${ }^{35}$ Ingram's graveyard humour, compensating for the lack of a gravestone, brings us back to the question with which this article began: whether his verses were actually carved, or whether he simply wanted to associate them with the act of carving. Looking again at the prefatory remark in the autograph manuscript of his verses, 'E $\pi$ lyó $\mu \mu \alpha \tau \alpha$ parietibus [T]turris Londinie[n] sis rudi cultro insculpta cum indies mortem expectaret, the close association it reveals between blunt knives and suffering for the faith may help to resolve a question posed earlier. We shall never know whether Ingram actually did scratch away painstakingly with his blunt knife to write his verses, making it blunter still; this article has argued that it is an unlikely scenario, and queried previous commentators' unquestioning acceptance of the story. But they would not have gone in that direction if Ingram had not pointed the way in the prefatory remark to his verses: Pollen translated this as 'Epigrams cut with a blunt knife on the walls of the Tower of London while he daily awaited death', but this is not the only possible rendition. Thanks to the wide remit of the Latin ablative, one can translate parietibus both as 'on the walls of the Tower of London' and as 'in the walls of the Tower of London'. If one assumes that this ambiguity is deliberate -- and Ingram had easily enough Latinity and playfulness to make this plausible -- it suggests that, while Ingram wrote his verses in the conventional manner with paper, ink and pen, he may have wished to imply that writing after torture was comparable to carving with a blunt knife, and certainly desired to associate himself with

\footnotetext{
33 Epigram II: 'ЕПІГРАММА iocosum in tumulum. / Pro tumulo lapides fodiuntur, viscera terrae, / Ut vivos dives possit habere suo. / Ast ego non quaero tumbam: sed vivida tumba / Pro nostro exangui corpore corvus erit.

34 These are in the overall title, and the titles to Epigrams II, IX and XV. Onomastic punning may also lie behind his apologies for literary error (see above), since 'ingram' was a contemporary word for 'ignorant' (OED). The Holtby MS does not employ Greek characters. However, the second thoughts of the poems' later transcriber are worth noting: his title runs 'Carmina quaedam R. P(?). Jo[ann]is Ingram M. descripta ex originali propriensis $\alpha v \tau \gamma \gamma \rho \alpha \varphi \omega$. prout sequitur.' (Collectanea, 41).

35 Scott L. Newstok, Quoting Death in Early Modern England: The Poetics of Epitaphs Beyond the Tomb (Basingstoke: Palgrave Macmillan, 2009); Peter Sherlock, Monuments and Memory in Early Modern England (Aldershot: Ashgate, 2008).
} 
the tradition of prisoners who did carve their names and thoughts on the walls of their jail. As he himself recognised, he needed a memorial.

\section{Appendix}

In an edition of Robert Southwell's verse printed in Edinburgh around 1600, a holy sonnet following his long poem 'St Peter's Complaint' is signed 'I.I.', and runs as follows:

A sinfull soule to Christ.

I Lurke, I lowre, in dungeon deepe of mynd, In mourning moode, I run a restles race, With wounding pangs, my Soule is sorelie pyn'd, My griefe it growes, and death drawes on a pace: What life can last except there come releace?

Feare threats, dispaire; my sinne infernall wage. I faint, I fall: most wofull is my cace, Who can me helpe, who may this storme assuage?

O Lord of life, our peace, our only pleage,

O blesfull light, who life of death hast wrought

Of heau'nlie loue the brightsome beame, and bage, ${ }^{36}$

Who by thy death from death and hell us bought,

Reviue (sic) my Soule, my sinnes, my sores redresse,

That liue I may with thee in lasting blesse. ${ }^{37}$

The initials are the same as Ingram's, and Southwell and he were imprisoned in the Tower of London at the same time. ${ }^{38}$ While I.I. is not an uncommon set of initials, and the sonnet could have been added to a manuscript or printed copy of Southwell's verse at many junctures, it is certainly possible to envisage a scenario where Ingram, within the Tower of London or outside, was shown 'St Peter's Complaint' and composed a response to it. ${ }^{39}$

\footnotetext{
36 i.e. 'badge'.

37 Saint Peters Complaint. With Other Poems [1600], p.30. Listed in Steven W. May and William A. Ringler, Jr., Elizabethan Poetry: A Bibliography and First-Line Index of English Verse, 1559-1603, 3 vols (London: Continuum, 2004), Vol.1, EV 10007 (unattributed). This edition of Southwell's verse (STC (2nd ed.) 22960) is usually termed the 'Waldegrave' edition after its printer, and was probably set up from a previous printed edition rather than a manuscript: see James H. McDonald, The Poems and Prose Writings of Robert Southwell, S.J.: A Bibliographical Study (Oxford: Roxburghe Club, 1937), 85.

38 Ingram was committed in March 1594; Southwell was committed on 28 July 1592 and removed to Newgate 18 February 1594/5 (Harrison, Prisoner Book, 260, 262).

39 This was first suggested by Herbert Thurston, 'Catholic Writers and Elizabethan Readers. IV. -- Philip Earl of Arundel', The Month, 86 (Jan-Apr 1896), pp.32-63.
} 
The printer of the volume in question, Robert Waldegrave, is known for subversive publishing of many kinds: most notoriously, the puritan Martin Marprelate tracts, and pirated copies of Sidney's Arcadia. ${ }^{40}$ The publication of Catholic matter is a departure from both these ventures, and seems on first consideration an unlikely departure for someone so strongly associated with the puritan cause. Developing a spread of interests in subversive publishing might, perhaps, have appealed to a printer who considered moral and ideological considerations less important than financial ones, and while there is nothing religiously provocative in I.I.'s poem, the fact that the poem is presented as a comment on 'St Peter's Complaint' does set up the question of whether its author was of Southwell's persuasion. To Catholic-minded readers, the inclusion of such a poem could have suggested that the printer had underground contacts among their co-religionists. On the other hand, given that the majority of Southwell's poems had been published in the mainstream before Waldegrave issued his edition, it seems more likely that he was simply capitalising on the volume's English success. I.I.'s poem could have been grafted in for many reasons and at many stages, but one possibility is that it was a manuscript addition to the copy-text.

While the circumstances of this poem's preservation are unusual, its writer's response to Southwell's verse is very much in keeping with those penned by others. Southwell is almost unique among Elizabethan poets in the level of active response he elicits from readers, and this accomplished sonnet, very much in the Southwellian manner, clearly responds to the theme of betrayal in 'St Peter's Complaint'. ${ }^{41}$ Southwell's poem is an unsparing exploration of religious abjection, designed to call its readers to repentance, and sometimes read as reflecting on the persecution which Southwell and other Catholics underwent. But St Peter's sin, that of denying acquaintanceship with Christ, maps him more onto the negative stereotype of the church-papist than onto the fortitude of Southwell himself, and of other Catholics who made no attempt to conceal their allegiance. The betrayal that such Catholics were tempted towards by their captors was typically of a different kind, to disclose information about their associates, and Ingram was concerned to present himself as not having revealed any damaging facts. In letters to his fellow prisoners, he wrote that 'he had 'neither named person nor disclosed anything as house or harbour, to any man, woman or child his damage in any climate whatsoever' and claimed that the torturer Richard Topcliffe had called him a monster of taciturnity for not giving way. ${ }^{42}$ So, supposing the sonnet was Ingram's work, he blamed himself for sin, but not Peter's sin of betrayal.

\footnotetext{
${ }^{40}$ See Joseph L. Black (ed.), The Martin Marprelate Tracts: A Modernised and Annotated Edition (Cambridge: Cambridge University Press, 2008), pp. xlix-1, and Katherine S. Van Eerde, 'Robert Waldegrave: The Printer as Agent and Link Between Sixteenth-Century England and Scotland', Renaissance Quarterly, 34 (1981): 40-78.

41 See Arthur F. Marotti, 'Southwell's Remains: Catholicism, Relics, and Print Culture in Early Modern England', chap.1 in Religious Ideology and Cultural Fantasy: Catholic and Anti-Catholic Discourses in Early Modern England (Notre Dame: Notre Dame University Press, 2005).

${ }^{42}$ Letters of July 1594: English Martyrs, ed. Pollen, 283-4.
} 
